\title{
The Role of Marketing Sea Ports for the Development of Tourism
}

\author{
Merita Murati \\ PhD Candidate, University Pavaresia of Vlora, Albania \\ Chamber of Commerce and Industry of Vlora Region \\ meri.murati@gmail.com \\ Rezarta Brokaj \\ PhD Candidate, University "Ismail Qemali" of VLora, Albania \\ rezartab@gmail.com
}

\section{Doi:10.5901/ajis.2014.v3n2p265}

\begin{abstract}
Marketing mix elements have a special role in the performance of maritime ports. The marketing of the sea ports have a special role in the development of tourism. The elements of marketing mix play an important role in maritime transport and port services, they remain important elements, but also complex elements about the high competition and service offered, recalling here the service features regarding port services in general. In this study will examine the available literature related to marine ports, high competition of their, the role of ports and maritime transport in the economy of countries, the role of marketing to improve port services, the role of the ports for development of tourism. This paper will conclude with a aspect of the marketing mix elements and in particular with the trend for development of marketing seaport and in the other hand the development of tourism in Vlora region. The study aims identifying the role of marketing for the development of the sea ports and the point of connection with the promoting the interests of the tourism. Questionnaires are used for gathering data. The questionnaires included both open-ended and closed questions.
\end{abstract}

Keywords: marketing, ports competition, tourism, maritime transport, marketing mix

\section{Introduction}

Even though service marketing has been developing dramatically in the past few decades the port industry has been largely neglected as far as marketing is concerned.

In order to understand a port as a commercial enterprise which is offering services to international markets, it is necessary to define its role in the chain of transport as well as the macroeconomic function of a seaport for the national economy and the geographical region where the port is located. As far as influence upon the region and national economy is concerned, a port has a double function, employment and transport.

A seaport has an important direct and indirect employment function in the region. The high value added which is produced in the port creates on the one hand a substantial in come and on the other revenues in form of taxes for the government. The macroeconomic function of the seaport has to be taken into account mainly in terms of transport and port policy (Stuchey, 1993).

As far as the transport function is concerned, this plays an important role as link in the international chain of transport. In this respect port services are part of the logistics costs for international trade. As a general rule it can be stated, that in the chain of transport 5 to 10 percent of the overall costs are port related (Stuchtey, 1993).

Not with standing the direct cost benefit ratios in the port, external economies and diseconomies can affect the national foreign trade depending on the efficiency of the seaport.

\section{The Elements of the Marketing Mix}

Marketing strategy, as being an indication of how each element of the marketing mix will be used to achieve the marketing objectives. This definition gives a complete reliance on the mix and therefore the utilization of the elements is the strategy. These give us strategies relating to products, distribution, and sales promotion and pricing. These elements of the marketing mix are sufficient for non-service businesses but services' marketing requires additional elements 
different from manufacturing. An expanded marketing mix presents a more appropriate model and reflects the traditional elements plus three new ones. These are people, processes and physical evidence (Payne, 1993).

\subsection{Product or service being offered}

Buying the service product is really buying specific benefits and value from the total offering. A service product is a complex set of value satisfaction. The buyers assign value in relationship to the benefits they receive. The service product can be recognized at several levels- the core product - basic service, the expected product - consists of the core product together with the minimal purchase conditions which need to be met, the augmented product - this area enables one product to be differentiated from another, and the potential product - this consists of all potential added features that may be of utility to the potential buyers (Oliver, 1995). Customers' expectations for different configurations of benefits and features vary by market segment. The brand name itself also becomes an important element of the augmented product. Brands can be major determining elements in the purchase of services and an important means of adding differentiation at the augmented product level.

\subsection{Price charged and terms associated with its sale.}

Pricing decisions are of great importance in determining the value for the customer and play a role in creating an image for the service. Price also gives a perception of quality. Pricing decisions for service are particularly important bearing in mind the intangible nature of services as well as the overall marketing strategy. The service marketers also need to understand the relationship between price and demand and how demand varies at different pricing levels. They also need to consider the cost of providing, services and how these vary over time and with level of demand. Two major types of costs, fixed cost and variable costs need to be identified. Fixed costs are those which do not vary with the level of output. They remain fixed over a given period and include buildings, furniture, staff cost, maintenance, etc. Variable cost varies according to the quantity of the service provided or sold. They include part-time employees' wages, expendable supplies, electricity, postage, etc. Many service businesses such as airlines have high levels of fixed costs because of the expense of the equipment and staff needed to operate them. Service managers need to understand how cost behaviour will vary at different levels of service output. This has important implications for decisions to expand capacity, as well as for pricing (Button, 1993).

\subsection{Promotion - the communication programme associated with marketing the product or service.}

The promotion of services is involved in a number of major areas, which are known as the communications rnix. The following elements are included- advertising, personal selling, sales promotion, public relations, word of mouth and direct mail. The choice of the communication mix for services involves decisions on such issues as whether to advertise, use personal selling or generate publicity. The choice of the medium is determined by decisions on how to create the most favourable awareness amongst the target audience.

\subsection{Place is the distribution and logistic function involved in making a firm's products and service available.}

The location and the channels used to supply services to target customers are two key decision areas. This is because services usually cannot be stored and will be produced and consumed the same time. The environment of the place and the way service is delivered are also vital and will be the part of the perceived value and benefits of the service. The choice of both distributions and channels for services largely depends on the particular requirements of the market and the nature of the service. Technology has changed the advantage to be gained by proximity of the service to the customer market. Electronic services have removed some of the need for the providers to be located on high streets and also the requirement for long opening hours to deliver their services (Cowell, 1984)

People are an essential element in both production and delivery of most services and they are becoming part of the differentiation by which service companies seek to create added value and gain competitive advantage. The success of marketing a service very much depends on the selection, training, motivation and management of people. The importance of people has led to a great interest in internal marketing, which aims to encourage effective behaviour by staff that will attract customers to the organisation. The idea behind internal marketing is to ensure that all members of the staff provide the best possible contribution to the marketing activities of the company and successfully complete all 
interactions with customers in a way that adds value to service encounters (Cowell, 1984).

Processes are all the procedures and routines by which a service is created and delivered to the customer including policy about some of the customer involvement and employee discretion issues. The processes by which services are created and delivered to customers are major factors within the services marketing mix, as services customers will perceive the service delivery system as apart of the service itself Identification of process management as a separate activity is a prerequisite of service quality improvement. While the people element is vital in the services marketing mix, no effort will overcome continued unsatisfactory process performance. Services processes can be analysed according to complexity and divergence. Complexity is concerned with the nature of steps and sequences that constitute the process, while divergence refers to the variability of them. Processes can be changed in terms of complexity or divergence to reinforce positioning or establish a new position (Cannon, 1998).

Physical evidence, also known as provision of customer service, is more demanding, requiring higher levels of service provided and the need to build closer relationships with customers. Physical evidence can be divided into two types: essential and peripheral. Essential evidence represents the key decisions made by the service providers about the design of the service product, which can be used to add significantly to the product surround. Peripheral evidence has little value on its own, but nevertheless can add tangibility to the value of the service provided. Where services are per formed at the location of the service organisation, physical evidence has an essential role to play. Familiarity is often a factor used by service franchise operators to provide reassurance, through physical evidence, of what the customer can expect (Payne, 1993). Each of these marketing mix elements interacts with each other and they should be developed so that they are mutually supportive in obtaining the best possible match between the internal and external environments of the organisation. In developing a marketing mix strategy, service marketers need to consider the relationship between the elements of the mix.

\section{The Nautical Sector in Albania}

Albania is a small country of $28,748 \mathrm{~km}^{2}$, situated in south-eastern Europe at the western part of the Balkan Peninsula. $1 / 3$ of its border is extended on the sea side, about $440 \mathrm{~km}$, making it a coastal country with favorable natural conditions which have not been properly assessed for the development of the Maritime Sector. During the period previous World War II, he Maritime Sector, as the whole economy was not developed enough. The means of transport mainly consisted of wood vessels of small tonnage, which were used for internal transport. International maritime legislation was poor. After the II World War II the International maritime transport was almost entirely concentrated in the Port of Durres and in some cases in the Port of Vlora, where the infrastructure / superstructure was poor with limited processing capacity. Albanian Commercial Marine Fleet was organized as a state enterprise with a capacity of approximately 90,000 TDW and carrying about 33 percent of freight volume of export - import products. Water transport was largely restricted to the northern area and active in the lake of Koman.

Even though, the Maritime Transport Sector, responding to the economic development of the country has a long history of development after World War II. The years 1979 - 80 were marked by an important economic development, especially in the minerals industry which determined a significant development in the Navy and Commercial Marine. The state decided to buy transatlantic ships from 12,500 to 16,000 TDW, with a total processing capacity of approximately 90,000 TDW, for the transportation of export - import. After the 90's the transition process towards the market economy involved the Albanian Commercial Fleet, as a result of which the maritime commercial fleet is currently represented by private owners, who have ships with a capacity of 1000-2000 TDW. Currently the fleet disposes of ships of around 11,000 TDW, with a total tonnage of about 99,000 TDW, but this important sector remains poor, both from technical and management point of view. Albanian owners continue to buy ships, especially general cargo but in general they are old and damaged with many technical problems lowering the standard of Albanian fleet in general. Inland Transport as a subsector of Maritime Transport includes not only transports in rivers and lakes, but also the transport of goods between the ports of Durres, Vlora, Saranda and Shengjin.

Nowadays, according to the modern world development model, the maritime traffic and maritime issues is considered as a crucial factor for our country's economic activity. For all coastal areas, sea has been a source of benefits for further economic development and international reputation. Infrastructure routes do not require funds to be built and maintained, but ports need to be built, as points of departure and arrival of the maritime routes and of connection with the land shipping. All activities in the marine include a wide range of different activities such as: maritime transport of passengers and goods, internal transport (cabotage), Tourism and sport cruisers. monitoring of maritime traffic and hydrography, shipbuilding industry, ports, protection of marine environment, training, certification of seafarers, marine 
resources (fisheries, gas / oil, tourism) Although Albania is a coastal country with a favorable geographic position, the maritime sector is in the process of development in the following areas: Legislation and the National Maritime law, Implementation of the requirements of international maritime conventions, sea ports, shipping, port safety and navigation security and environmental protection.

Sea Ports in Albania Maritime ports are an important component of Maritime Sector playing an important role not only in the development of transport, but also in the development of international trade and economy. Maritime Port of Durres is located about $38 \mathrm{~km}$ away from Tirana, in the north side of Durres bay as the largest port of Albania and already considered as the main gate of the eighth corridor. It has a processing capacity of about $75 \%$ of goods of import export-and 4 million of goods processing each year. This is an important port where are processed the passenger ferries, RO / RO ships, container ships and cargo, genera bulk cargo and fuel. Based on The Master Development and the Land Use Plans, numerous projects are carried out for the rehabilitation of the infrastructure I superstructure and administrative restructuring of the Port, with World Bank funding, the European Community, European Investment Bank etc.

Maritime Port of Vlora is Albania's second port in importance, situated about $90 \mathrm{~km}$ south of Port of Durres and is defined as the second entry gate of Corridor VIII-th. In this port are processed ferry boats with passengers and goods, covering about 10\% of the export-import goods. In Vlora District is situated Himara port with no role in the processing volume of goods and will serve as a secondary port, mainly with tourist purposes for Himara and surrounding areas.

Maritime Port of Shengjin, situated about $60 \mathrm{~km}$ in the north side of Durres port processes different bulk commodities and fuel. Based on the Master Plan, the port is attempting to increase its boarding and processing capacities, the safety of navigation, the infrastructure and superstructure with state budget financing. Especifically, the work is focused on the building of the new berth of $70 \mathrm{ml}$, destined to the preparation of ships, ferries and cargos, the passenger terminal and breakwater. In the near perspective, with the construction of Durres-Kukes-Morine highway, the port of Shengjin will be an important hub for Kosovo's access to the sea.

Maritime port of Saranda is a secondary port located about $160 \mathrm{~km}$ in the south of Port of Durres, where are processed passenger ships and goods. This port is also developing for a tourism destination for passenger ships processing, whereas the goods procession will take place on the Bay of Limion (about $3 \mathrm{~km}$ from the port city).

Jetty port of Porto Romano, Durres is being built by the company Romano Port JSC on the basis of the final concession agreement, this port serves for the discharge of oil, gas and their sub--products, with facilities for increasing the level of safety and environmental protection. This is the first port in the Albanian territory built on the basis of a concession agreement.

Port (Terminal) of Vlora Bay is being built by the Italian company La Petrolifera Italo Albanian under a concession agreement with the Albanian State. Also, the construction of this port will be assigned to the removal and disposal of oil, gas and their derivatives, will establish processing facilities for increasing the level of safety and environmental protection.

\section{Tourism and Marina Development}

Coastal Tourism Development in Albania is in its infancy. The present restriction on small motor crafts in Albanian coastal waters has till today blocked the development of marina facilities along this coast. But this is all expected to change rapidly in the near future, as it has in recent years in the neighboring countries along the Mediterranean. Tourism will become one of the major sources of income for the country.

Tourism - All coastal cities have significant tourism potential and will be an attraction to both national and international tourists. Furthermore, the various marine entry points into the country will in the near future become the gateways to tourism into the inlands with mountain resorts and eco ventures

The beach areas cater at this moment mainly for national holiday makers and the Consultants have observed seemingly uncontrolled development along certain sections of coast and beach line, of small and medium size hotels and apartment blocks catering for these temporary guests. However, there are still large coastal sections untouched, which provides opportunities for international resort developers to implement large scale integrated tourist resorts, such as 1000 room resort hotels, with extensive facilities including golf courses and marinas, catering for the affluent regional and international tourists.

Tourists will first arrive by air and road, but in increasing numbers from the Mediterranean, by ferry, cruise liner and soon by private yachts.

Marinas - During recent years and till today Albania does not allow the use and operation of motor yachts in its coastal waters due to security reasons and illegal transport of goods and persons. However, with significant increase of 
the government border security enforcement and the impending opening of borders, this restriction is expected to be lifted in the near future.

Due to the lifting of this ban on yachting, the restrictions on travelling of national residents and the development of Albania and its beaches as a Foreign Tourist Destination, a strong demand for Marina Facilities along the coast is expected. Several applications for concessions to build and operate such marinas have already been received by the Albanian Government.

In order to benefit most from the economic opportunities of the influx of foreign tourists, those tourists should be concentrated in the areas where entertainment outlets are present and where they can spend their money. At the moment, and still in the foreseeable future, these locations will be the existing traditional coastal cities. It is therefore strongly recommended to develop the first marinas at those locations, as it is less economically attractive to have the tourists spend their time in isolation. This may happen later, when further development of tourist facilities along the rest of the coast is progressing, but in the interest of the economy, and the development of employment opportunities in the coastal cities it is recommended to "cream off" this market first.

At present the traditional city ports do not provide for marina and yacht landing facilities and space, but it is foreseen that in the coming years these ports will be flooded with pleasure vessel arrivals and berthing, and this is difficult to prevent. Space and facilities will have to be planned in each of the city ports, apart from other dedicated marina and resort developments along the coast.

In considering the approach to a Port Development Strategy the Consultants recognize the following significant factors from the previous chapters:

Tourism -Tourism will be an important component of the future Albanian economic growth. In order to make full use of the benefits of coastal tourism, as well as providing efficient corridors for tourists to visit the Albanian hinterland resorts, the Traditional City Ports are vital. These are not only ideal for this purpose, but will certainly rapidly develop as such in the medium term, when Albanian waters are opened up for yachting. This significant "green" tourism pressure will be an impediment to operation and development of commercial port activities.

Commodities and the transport corridors - Albania is set to become a major entry point into the European Transport Corridor VIII, which is considered vital for the economic growth of the South Eastern European region. Furthermore the landlocked neighbor countries, Kosovo and Macedonia, will largely rely on a maritime entry point for their import and export flows. However, to achieve optimum economic benefits for these corridors, as well as for the developing Albanian National Industry and Trade, full use must be made of Economies of Scale to reduce transport unit rates. Considering the relative short, $350 \mathrm{~km}$, Albanian coast line, and one major and modern port will be effective. Such "Balkanport" can be the "Europort" for South- East Europe.

The dates for the tourists in Vlora Sea Port in years (2009-2013):

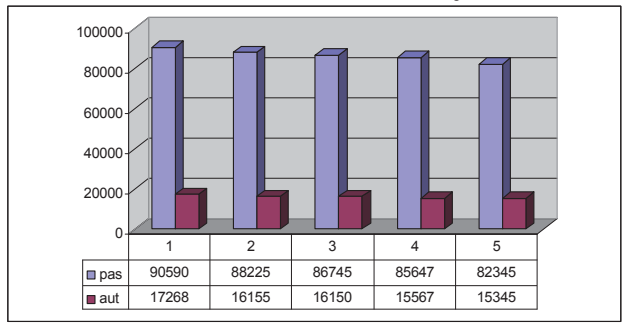

The trend of tourism in years (2009-2013)

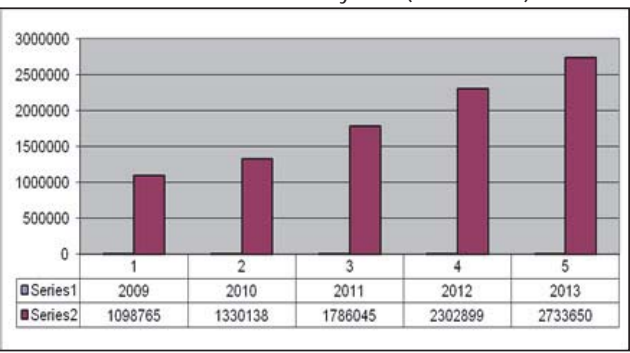




\section{Conclusions}

Marketing in services has been developing very rapidly, first in services such as travel, leisure, progressively dominating every domain of life. Marketing is becoming a necessary seaport management activity due to changes in the environment and the effects competition. Becoming market-oriented and aggressive in both attracting and retaining customers may no longer be a choice but a necessity for seaports. In the Albanian country there was no need for marketing since there was no market economy and the exchange of goods and services was centrally planned, within each country and between the members of the bloc. The countries were able to operate independently and implement principles of the free market. The emergence of the market economy brought the need and desire for marketing. In Albania marketing efforts were first noticed in consumer goods and services but as the state owned enterprises were exposed to reconstruction and privatisation, marketing became an important part of their economic activities. This also affected heavy industry, transportation and of course the maritime economy including ports.

Seaports in the Economy face many challenges, some instituted by the government, others created by competitors within the same industry, and those resulting from the broader macroenvironment. Seaports are emerging from the protective umbrella of the public sector and to maintain and grow their business, new strategies are necessary. Like many other service businesses, being able to respond rapidly to changing market forces and international trends, being innovative and entrepreneurial, and market-oriented will become the characteristics of successful seaports.

Research on seaport marketing, although still at an embryonic stage, is emerging. The rate of emergence however, is occurring at a faster speed for practitioners in the seaport sector than in academic circles. As competition heightens and further value is placed on trade facilitation, practitioners and governments will become more interested in how seaports can increase revenues and cargo throughput whilst balancing local community issues.

As there is divergence among practitioners and researchers over what constitutes marketing in seaports, the seaport marketing literature would benefit from rigorous theoretical definitions of key marketing concepts as applied to seaports. Greater joint efforts between practitioners and researchers could help to increase understanding of the needs of the seaport sector.

Vlora has a very favorable geographical position and a large sum of natural and cultural assets. Tourism is the economic future seen for the region developing. Tourism industry is a promoter of sustainable development but it will bring better management and stewardship that have appropriate effects and provide a long-term development, canned and preserved natural and cultural resources. Tourism development will help in employment and total income per destination; accelerated social and economic development throughout the destination; Improvement of living conditions at the destination; beginning of economic activities; Creating a positive international image of the country as tourist destination; increase foreign currency income and tax revenues for the government; social tourism development, and sustainable environment.

However the challenges that face in front of sustainable regional development are numerous like Control of the territory, territory management, and territory regulation. County of Vlora Region should develop a research project for the Region of Vlora, anticipating the development of the region for a long period of time. From this research project will emerge that will have regional needs in the future, which should be made public, in order to attract foreign investors and tourists.

\section{References}

Alderton,P. M.(1999) Port Management and Operations, London: LLP Reference Publishing.

Atkinson, R. D. and Court, R. H. (1998) The New Economy Index: Understanding America's Economic Transformation, Washington, DC: Progressive Policy Institute.

Baird, A. J. (2000) "Port privatisation: Objectives, extent, process, and the UK experience", International Journal of Maritime Economics, 2 (3), 177-194.

Booms, B. H. and Bitner, M. J. (1981) "Marketing strategies and organizational structures for service firms". In Marketing of Services, Donnelly and George: American Marketing Association, pp. 47-51.

Branch, A. E. (1998) Maritime Economics: Management and Marketing, 3rd edn, Cheltenham United Kingdom: Stanley Thornes.

Brooksbank, R. W. (1991) "Successful marketing practice: A literature review and checklist for marketing practitioners", European Journal of Marketing, 25 (5), 20-29.

Bureau of Transport and Regional Economics (2002) Australia's Seaborne Containerised Freight: Forecasts to 2010-11, Working Paper 50, Canberra: Commonwealth of Australia.

Cahoon, S. C. (2004) Seaport Marketing: A Census of Australian Seaports, unpublished PhD thesis, Tasmania, Australia: University of Tasmania. 
Chang, T. Z. and Chen, S. J. (1998) "Market orientation, service quality and business profitability: A conceptual model and empirical evidence", Journal of Service Marketing, 12 (4), 246-264.

Cowell, D. (1993) The Marketing of Services, reprint edn., Oxford: Butterworth- Heinemann.

Doyle, P.(1995) "Marketing in the new millennium", European Journal of Marketing, 29 (13), 23-41.

Edgett, S. and Parkinson, S. (1993) "Marketing for service industries - A review", Service Industries Journal, 13 (3), 19-39.

Figwer, H. (1999) "Marketing orientation in Polish seaports". In Strategic Management in the Maritime Sector: A Case Study of Poland and Germany, Ed. M., Roe, Aldershot, England: Ashgate Publishing, pp. 16-28.

Haezendonck,E., Pison, G., Rousseeuw, P., Struyf, A. and Verbeke, A. (2000) "The competitive advantage of seaports", International Journal of Maritime Economics, 2 (2), 69-82.

Heaver, T., Meersman, H. and Van de Voorde, E. (2001) "Co-operation and competition in international container transport: Strategies for ports", Maritime Policy and Management, 28 (3), 293-305.

Helling, A. and Poister, T. H. (2000) "U.S maritime ports: Trends, policy implications, and research needs", Economic Development Quarterly, 14 (3), 300-315.

Hult, G. T. M., Cravens, D. W. and Sheth, J. (2001) "Competitive advantage in the global marketplace: A focus on marketing strategy", Journal of Business Research, 51 (1), 1-4.

Industry Commission (1993) Port Authority Services and Activities, Report No. 31, 31 May, Canberra: Australian Government Publishing Service.

Jarratt, D. and Fayed, R. (2001) "The impact of market and organizational challenges on marketing strategy decision-making: A qualitative investigation of the business-to- business sector", Journal of Business Research, 51 (1), 61-72.

Mangan, J. and Furlong, F. (1998) "Strategies for developing port administration in Ireland", Maritime Policy and Management, 25 (4), 349-360.

Mester, B. (1991) "Marketing from the port's point of view". In Port Management Textbook: Volume 3-Port Marketing, Ed. R. W. Stuchtey, Bremen: Institute of Shipping Economics, pp. 33-58.

Misztal, K.(1999) "Marketing management in seaports". In Strategic Management in the Maritime Sector: A Case Study of Poland and Germany, Ed.M.Roe, Aldershot, Ashgate Publishing, pp. 49-63.

Murphy, D., ed., (1991) The Marketing of Ports and Harbours, Melbourne: United Nations Economic and Social Commission for Asia and the Pacific.

Notteboom,T. E. and Winkelmans, W. (2001) "Reassessing public sector involvement in European seaports", International Journal of Maritime Economics, 1 (3), 242-259.

Palmer, S. (1999) "Current port trends in an historical perspective", Journal for Maritime Research, December, 1-14.

Peters, H. J. F. (2001) "Developments in global sea trade and container shipping markets: Their effects on the port industry and private sector involvement", International Journal of Maritime Economics, 3 (1), 3-26.

Pieczek, A.U. (2000) Analysis of Marketing Strategies in Polish Ports, unpublished PhD thesis, United Kingdom: University of Plymouth.

Pieczek, A.U. and Roe, M. S. (2000) "Analysing marketing strategies in international ports of Poland: A concept of the Port of Gdynia", Proceedings of the Society for Marketing Advances Conference, November, Orlando, pp. 1-4.

Schulten, U. (1991)"Marketing from the customer's point of view". In Port Management Textbook: Volume 3 - Port Marketing, Ed. R. W. Stuchtey, Bremen: Institute of Shipping Economics, pp. 15-32.

Slack, B., Comtois, C. and Sletmo, G. (1996) "Shipping lines as agents of change in the port industry", Maritime Policy and Management, 23 (3), 289-300.

Stuchtey, R. W. (1991) "Port competition and marketing". In Port Management Textbook: Volume 3 - Port Marketing, Ed. R. W. Stuchtey, Bremen: Institute of Shipping Economics, pp. 1-14.

Whitaker, C. (2002) "Ensuring long-term sustainability of our ports: What should we be doing today as an investment for tomorrow?" Paper presented to Pan Pacific 2002, California, pp. 1-18.

Winkelmans, W. (2002) "Strategic seaport planning: In search of core competencies and competitive advantage", Ports and Harbors, April, 17-21.

Zaheer, R. (1998) "Professional is the key to success in port management", in Nautical Institute, eds, The Work of the Harbourmaster: A Practical Guide, 2nd, London: Nautical Institute, pp. 71-74.

Chamber of commerce and Industry of Vlora Region, the department of business

The strategy for developments of ports, Ministry of transport in Albania.

Sea Port of Vlora, the department of information and statistics

Vlora Municipality, the department of tourism and statistics 
